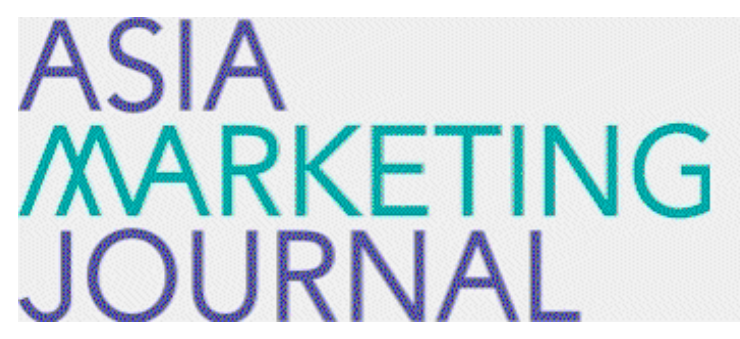

ASIA MARKETING JOURNAL

Volume 10 | Issue 2

Article 5

7-30-2008

\title{
온라인 고객 리뷰의 분류 항목별 차이 분석
}

\section{So Young Yang}

Hyung Su Kim

Young Gul Kim

Follow this and additional works at: https://amj.kma.re.kr/journal

Part of the Marketing Commons

\section{Recommended Citation}

Yang, So Young; Kim, Hyung Su; and Kim, Young Gul (2008) "콘라인 고객 리뷰의 분류 학목별 차이 분석," Asia Marketing Journal: Vol. 10 : Iss. 2 , Article 5.

Available at: https://doi.org/10.53728/2765-6500.1216

This Article is brought to you for free and open access by Asia Marketing Journal. It has been accepted for inclusion in Asia Marketing Journal by an authorized editor of Asia Marketing Journal. 


\title{
온라인 고객 리뷰의 분류 항목별 차이 분석: \\ 채널, 제품속성, 가격을 중심으로
}

\section{Analysis of Differences between On-line Customer Review Categories: Channel, Product Attributes, and Price Dimensions}

\author{
양 소 영(Yang, So-Young)* \\ 김 형 수(Kim, Hyung-Su)** \\ 김 영 걸 $(\mathrm{Kim}, \text { Young- } \mathrm{Gul})^{* * *}$
}

기업과 소비자 간의 온라인 커뮤니케이션 활성화로 인하여 기업과 소비자 모두 제품에 대한 경험 과 지식을 공유하는 온라인 고객 리뷰에 많은 관심을 기울이고 있다. 본 연구에서는 내용 분석법을 통해 온라인 소비자 리뷰들을 맥락단위로 분류하고 분류항목을 도출함으로써 채널(자사홈페이지/쇼 핑몰), 제품속성(탐색재/경험재), 가격(고가/저가)에 따른 차이 분석을 시행하였다. 분류 항목의 도출 은 ACSI 모델의 구성 항목들을 근간으로 실제 리뷰의 반복적 분류를 통해 이루어졌으며 총 3 단계로 나누어졌다. 1 단계에서는 일단 제품과 서비스로 분류하고, 2 단계에서는 제품에 대해서 기능, 디자인, 가격, 구매동기, 제안/사용팁, 그리고 추천/재구매를, 그리고 서비스에 대해서 AS/업그레이드, 배송/ 기타제조사와 유통사 등 총 8 개 분류 항목을 도출하였으며, 3 단계에서는 실제 제품 리뷰 내용을 바탕 으로 2 단계 분류 항목의 세부항목으로 작성되었다. 분류 항목별 차이 분석 결과, 총 8 개의 분류 항목 에서 모두 유의한 차이점을 보였는데, 특히 채널별 차이를 보기 위해 분석한 홈페이지와 쇼핑몰에서 의 리뷰 내용이 가장 두드러진 차이를 보이고 있었다. 한편, 쇼핑몰의 특성을 나타내는 가격과 배송/ 기타 서비스 항목을 제외하고는 맥락단위의 개수가 홈페이지에서 더 많이 나타남으로써 기업 홈페이 지 상의 소비자 리뷰가 쇼핑몰 상의 소비자 리뷰보다 더욱 상세하다는 것을 알 수 있었다. 제품에 대 한 만족도 역시 홈페이지의 리뷰에서 더 큰 것으로 나타났으며, 탐색재와 경험재로 나누어 보았을 때 디자인, 구매동기, 추천/재구매, $\mathrm{AS} /$ 업그레이드 서비스, 그리고 배송/기타 서비스 항목에서 서로간의 차이가 있었으나, 전반적인 만족도의 차이는 없었다. 또한, 가격별로 보았을 때는 디자인, 가격, AS/ 업그레이드 서비스에서 고가와 저가의 차이를 볼 수 있었으나 전반적인 만족도의 차이는 없었다.

핵심개념: 고객 리뷰, 구전, 고객 지식, 내용 분석

KT마케팅연구소(syyang@ business.kaist.edu)

** 한국과학기술원 테크노경영대학원 경영공학 박사(hskim@business.kaist.edu)

*** 한국과학기술원 경영대학 교수(ygkim@business.kaist.ac.kr) 


\section{I. 서 론}

오늘날 인터넷이 활성화되고 인터넷 상거래를 이용하는 소비자가 증가하면서 인터넷을 통한 제품의 경험과 지식의 공유가 활발해지고 있다. 공유된 경험과 지식은 직, 간접적으로 소비자들 의 구매의사결정에 영향을 미치기 때문에 기업 에서는 이들의 내용 및 영향력에 대해 많은 관 심을 기울이고 있는 실정이다(김형수 외 2008). 고객이 상품 구입, 사용 후기 및 만족 등 총체 적인 경험을 웹페이지 상에서 작성한 것을 '온 라인 고객 리뷰'라고 하며, 이러한 온라인 고객 리뷰는 마케팅 분야에서 주로 연구되어온 구전 의 한 종류라고 할 수 있다. 소비자들의 구매 의 사 결정에 구전이 중요한 역할을 한다는 것은 많은 연구를 통해 밝혀져 왔으며(Arndt 1967; Swan and Oliver 1989), 인터넷의 발달로 인하 여 현재 그 역할이 더욱 중요해지고 있는 실정 이다(Subramani and Rajagopalan 2003).

한편, 연구 방법론의 관점에서 보았을 때, 전 통적인 구전에 대한 연구는 구전의 본질이 사 람간의 대화의 일종이라는 점에서 구전의 발신 자나 수신자와의 심층 인터뷰를 수행하고, 이를 통해 구전 메시지를 회상하는 방법 등을 사용 해왔다(Sundaram et al. 1998). 반면에 온라인 구전은 이미 인터넷 상에 문서화가 되어 있기 때문에 연구자가 개입하지 않고 현상을 있는 그대로 관찰하고 연구할 수 있다는 편의성을 내포하고 있다. 하지만 이러한 온라인 구전연구 의 중요성과 방법론상의 편의성에도 불구하고 온라인 구전의 구체적인 내용과 구성에 대한 연 구는 활발하게 이루지지 못하고 있는 실정이다.
또한, 온라인 고객 리뷰는 소비자 관점뿐만 아니라 기업 관점에서도 그 중요성을 찾을 수 있다. 온라인 고객 리뷰에는 소비자들이 제품이 나 서비스를 사용하면서 느낀 다양한 의견, 불 평, 제안 등을 포함하고 있는데, 이러한 소비자 의 직접적인 리뷰는 기업의 향후 운영에 중요 한 방향을 제시해줄 수 있는 핵심 고객지식의 일종이기 때문이다. 예전부터 고객의 선호도나 구매 경험, 제안, 의견 등은 기업의 핵심 활동 인 신상품 개발 프로세스 등에서 중요하게 여 겨져 왔지만(Joshi and Sharma 2004), 과거에 는 직접적으로 고객의 의견을 획득하기 어려웠 기 때문에 연구의 한계가 존재했던 것이 사실 이다. 하지만, 현재의 온라인 고객 리뷰는 전통 적인 소비자 구전과 유사한 역할을 하고 있는 동시에 더욱 용이하고 적은 비용으로 획득할 수 있는 기회를 기업에게 제공해주고 있다. 그 럼에도 불구하고, 온라인 소비자 리뷰에 대한 연구가 활발하지 못했던 이유는 이에 대한 뚜 렷한 분석 기준이 아직까지 마련되어 있지 않 았고, 이 때문에 기업 역시 단순한 일회성 대응 에 머무르고 있는 뿐, 온라인 소비자 리뷰를 내 부의 지식으로 전환함에 있어서는 한계점을 보 이고 있는 것이 사실이다. 이에 따라 본 연구에 서는 내용 분석법을 통해 온라인 고객 리뷰를 구성하는 분류 항목을 도출하고, 도출된 분류 항목에 따라 채널, 제품속성, 그리고 가격에 따 른 고객리뷰의 차이를 분석해 보고자 한다. 이 를 위해 먼저 온라인 구전과 고객 지식에 대한 이론적인 배경을 바탕으로 연구문제를 제시한 후, 관련 문헌 연구와 실제 고객 리뷰에 근거해 온라인 소비자 리뷰의 내용을 구성할 수 있는 분류 항목을 선정한다. 또한, 이 분류 항목을 
기준으로 실제 온라인 소비자 리뷰의 내용을 최소의 의미를 가진 맥락단위로 분류할 것이다. 이어서 도출된 분류 항목별 맥락단위의 개수를 바탕으로, 리뷰가 존재하는 채널(자사 홈페이지 또는 쇼핑몰), 제품의 속성(탐색재 또는 경험 재), 그리고 제품의 가격(고가 또는 저가)에 따 른 분류 항목별 차이와 고객들의 만족도 차이 에 대해 분석할 것이다.

\section{II. 이론적 배경}

\section{1 구전과 온라인 구전}

구전은 Whyte(1954)가 이웃간의 창문형 에 어컨의 수용에 대한 연구에서 에어컨의 수용이 기기의 가시성과 이웃간의 사회적 근접성에 달 려있음을 이야기하면서 처음 제기된 후 많은 학자들에 의해 연구되었다. 연구자들마다 구전 을 조금씩 다르게 정의하고 있지만 일반적으로 는 “소비자들이 상업적인 목적을 갖지 않고 특 정한 제품이나 서비스에 대한 개인적인 경험을 주제로 하는 커뮤니케이션”이라고 정의될 수 있다. 온라인 구전에 대해서 Chatterjee(2001)는 전통적인 구전이 온라인 매개체를 통해 이루어 진 멀리 떨어져있는 많은 사람들간의 (many to many) 커뮤니케이션이라고 하였다. 또한 이 은영(2004)은 온라인 구전을 인터넷을 기반으 로 소비자들이 자신의 경험이나 지식에 기초한 제품이나 소비관련 정보의 언급이라고 하였다. 이와 같이 몇몇의 연구들에서 온라인 구전에 대한 정의를 종합해보면 “다수의 사람들이 인
터넷을 매개체로 하여 회사의 제품이나 서비스 에 대한 그들의 경험이나 지식을 이야기하는 것”이라고 정의 내릴 수 있다.

전통적인 구전과 온라인 구전은 정의만 비교 해보아도 차이점을 쉽게 찾을 수 있는데 바로 인터넷을 매개체로 한다는 점이다. 그리고 그것 을 통해 많은 사람들이 시공간을 초월하여 함 께 커뮤니케이션을 할 수 있어 구전의 효과가 극대화되었다. 따라서 소비자들은 온라인 구전 을 더욱 쉽고 많이 접할 수 있게 되었고 더불 어 기업들의 구전에 대한 관심도 증폭되었다.

\section{2 구전과 소비자행동}

구전이 기업에서 고려해야할 중요한 요인이라 는 것은 많은 논문에서 연구되어 왔다. 기존의 연구들에서 제품의 선택에 있어 구전이 많은 영향을 미치고 있다고 밝혔을 뿐만 아니라 (Herr et al. 1991) 구전은 소비자행동의 중요한 결정 요소 중 하나로 간주되고 있다(Hennig-Thurau and Walsh 2003). 구전은 발신자와 수신자가 존재하는 커뮤니케이션이기 때문에 발신자의 관 점에서 구전이 일어나게 되는 원인과 수신자의 관점에서 구전이 미치는 영향과 효과로 크게 나 누어 연구가 진행되어 왔다(김미주, 황의록 2004). 따라서 본 연구에서도 크게 구전의 발생과 영 향으로 나누어 살펴보겠다.

구전의 발생은 크게 해당 제품이나 서비스 자 체에 대한 만족 및 경험과 같은 소비후 행동 (postconsumption behavior)적인 요소와 소비자 로 하여금 그러한 구전 커뮤니케이션을 하도록 자극하게 만든 동기적 요소로 구분할 수 있다. 만족은 고객이 소비에 대해 내리는 가장 대표 
적인 평가로서 제품이나 서비스에 대한 소비전 의 기대의 불일치 정도에 따라 결정된다(Oliver and Winer 1987; Anderson and Sullivan 1993). 이러한 고객 만족의 결과로서 고객들은 충성도 를 갖게 되고 긍정적인 구전을 하게 된다(Selnes 1993). 이와 반대로 고객이 불만족을 했을 때에 는 부정적인 구전을 하게 된다(Richins 1983). 하지만 이러한 불만족을 기업이 잘 해결했을 때에는 오히려 긍정적인 구전으로 이어지기도 한다(Singh 1990; Tax et al. 1992; Bowman and Narayandas 2001).

다양한 연구에서 구전은 다양한 제품군의 소 비의사결정에 영향을 미친다고 발견되었는데 (Arndt 1967; Swan and Oliver 1989), 그 영 향력의 정도는 구전의 특성에 따라 다르게 나 타난다. 정재학과 김영찬(2004)은 구전의 원천 에 따라 친구, 전문가, 인터넷으로 분류하여 실 제 소비자의 제품 구매 행위에 이들이 차별적 으로 영향을 미치며 친구 구전이 가장 영향력 있음을 밝혀내었다. 또한 구전정보의 특성에 따 라서도 영향력이 달라지는데, 온라인 구전정보 는 부정적이고 평가적일 때 긍정적이고 사실적 일 때보다 소비자들에 대한 구매영향력이 더 크게 작용한다(이태민, 박철 2006). 임종원과 이은영(2007)은 온라인 구전정보를 동의성, 생 생함, 커뮤니티 상호작용, 접근성, 유연성으로 제시하고 이들이 신뢰성과 전달성이라는 매개 변수를 통해 구전효과와 구전활동에 영향을 주 는 통합모델을 제시하였다. 또한 차태훈과 이경 아(2006)는 온라인 쇼핑에서의 사용후기가 구 매의사결정에 영향을 미치는 이유를 제시하였 는데, 사용후기를 읽는 독자가 사용후기를 남긴 과거 구매자들을 자신과 유사하다고 믿으며, 동
시에 온라인 쇼핑 및 정보탐색 상황이 통제가 능하기 때문에 이를 받아들이는 경향을 강하게 나타냄을 밝혔다.

구전 자체의 내용과 특성에 대해서 과거의 구 전은 문서화되지 않는 사람사이의 대화였으므 로 조사에 한계가 있었다. 그러나 온라인 구전 은 기록이 남아있기 때문에 구전 자체의 특징에 대한 연구가 용이해졌다. 박철과 정수연(2006) 은 종합몰과 커뮤니티에서 전문몰보다 구전의 양이 더 많고, 종합몰의 구전이 더욱 긍정적임 을 밝혀냈다.

기업에서도 구전의 중요성을 인지하고 다양한 활동에서 구전을 이용하고 있다. 특히 구전은 신제품의 확산에 중요한 역할을 하는데(Sheth 1971), 많이 익숙한 제품에 비해 신제품들은 불 확실성이 크기 때문에 소비자들은 주변인들의 구전에 의존하게 되기 때문이다. 뿐만 아니라 간접적인 고객참여활동인 구전은 직접적인 고 객참여활동인 협조에 영향을 주는 변수로서 고 객과 기업간의 관계발전을 위한 초석이기도 하 다(이유재, 이수진 2006).

\section{3 고객지식}

조직 내에서의 지식 경영이 많은 주목을 받고 있지만 상대적으로 조직의 범위를 벗어나는 고 객 지식에 대한 연구는 많지 않았다(GarciaMurillo and Annabi 2002). 하지만 마케팅 분 야에서의 고객 지식은 새로운 시장 기회를 찾 고 장기적으로 고객과의 관계를 맺는 중요한 요 소의 하나로 인식되어왔다(Rollins and Halinen 2005). 고객 지식은 크게 고객에 대한 지식과 고객의 지식으로 나누어 볼 수 있다(Rollins 
and Halinen 2005). (표 1>에서와 같이 고객에 대한 지식은 고객정보에서 한 단계 발전한 것 으로서 기업에서 고객 데이터, 고객 정보의 분 석을 바탕으로 획득한 지식이다. 반면 고객의 지식은 고객이 특정 제품 및 서비스에 대해 가 지고 있는 지식으로서 사용 경험 등이 해당된 다. 본 논문에서 주로 다루고자 하는 온라인 고객 리뷰가 이러한 고객의 지식에 해당된다. Park and $\operatorname{Kim}$ (2003)이 제시한 동적인 고객 관 계 관리의 개념적 틀에서는 기업과 고객의 관 계에 따라 발생하는 정보를 고객의 정보, 고객 을 위한 정보, 고객에 의한 정보의 3 단계로 나 누어 보았는데, 이 중에서 온라인 고객 리뷰를 포함하는 고객에 의한 정보는 기업과 고객과의 관계가 확장 단계일 때 고객으로부터 발생하는 정보로서 이를 관리하는 것은 관계 확장을 위 해 기업에 있어 점차 필수적인 일이 되고 있다 (Kim and Kim 2008).

고객 지식의 중요성은 예전부터 강조되어왔으 나 실질적인 고객 지식 획득의 어려움으로 인 하여 많은 관심을 받지 못하였다. 기업들이 고 객지식관리의 중요성을 인지하면서도 실행에 옮기지 못한 이유는 고객 지식을 통해 얻는 이 익에 비해 고객 지식을 획득하는 비용이 많이
발생했기 때문이다. 지금까지 고객지식은 고객 을 직접 상대하는 판매원, 고객의 전화, 편지 등을 통해 주로 획득되었고, 기업에서는 보다 양질의 고객 지식을 얻기 위해서 실제 고객으 로 구성된 조직을 만들어 운영하기도 하였다 (Nonaka 1998). 최근에는 인터넷의 발달로 기 업홈페이지나 블로그를 통해 고객들은 쉽게 자 신의 의견을 표현할 수 있게 되었으며 동시에 기업에서도 이전보다 훨씬 적은 비용으로 고객 지식을 획득할 수 있게 되었다(김형수 외 2008). 가장 대표적인 예로 기업이 브랜드 커뮤니티를 통해 고객 지식을 획득하는 것을 들 수 있다 (Muniz and O'Guinne 2001; 강신형 2005).

\subsection{ACSI}

ACSI는 American Customer Satisfaction Index 의 약자로서 1994년에 미국미시건 경영 대학의 Stephan M. Ross 교수와 ASQ(American Society for Quality), 세계적 컨설팅 회사인 CFI Group 이 연구하여 가정의 소비 경험을 측정하기 위 해 개발되었다. ${ }^{1)} \mathrm{ACSI}$ 모델은 중간에 위치하 고 있는 $\mathrm{ACSI}$ 를 기준으로 고객 만족의 선행변 수인 고객 기대, 인지된 품질, 인지된 가치와

〈표 1〉 고객 지식의 분류

\begin{tabular}{|c|l|}
\hline 분류 & \multicolumn{1}{|c|}{ 의미 } \\
\hline $\begin{array}{c}\text { 고객에 대한 지식 } \\
\text { (Knowledge about Customer) }\end{array}$ & $\begin{array}{l}\text { 고객의 구매 데이터 등을 통해 찾아낸 구매패턴, 선호도 등과 같은 체계 } \\
\text { 화된 정보. }\end{array}$ \\
\hline $\begin{array}{c}\text { 고객의 지식 } \\
\text { (Knowledge from Customer) }\end{array}$ & $\begin{array}{l}\text { 고객이 제품 혹은 서비스에 관련하여 가지고 있는 지식. 고객이 소유하 } \\
\text { 고 있는 지식. }\end{array}$ \\
\hline
\end{tabular}

주) Source: Adopted from Rollins and Halinen 2005

1) Source: http://www.acsi.org 
결과변수인 고객 불평, 고객 충성도의 구성 개념 (Construct)을 가지고 있다. 〈그림 1〉은 ACSI 모델을 나타낸다. ACSI 모델은 고객 만족도와 이와 관련된 선행, 후행변수를 가지고 있다는 점에서 의미가 있으며, 고객만족을 중심으로 한 선후행적 요소들 간의 인과관계는 기업의 $\mathrm{CRM}$ 전략 수행에 대한 고객관점의 평가 프레임워 크로도 응용되어 왔다(김형수와 박찬욱 2006;

Kim and Kim 2008).

〈그림 1〉ACSI

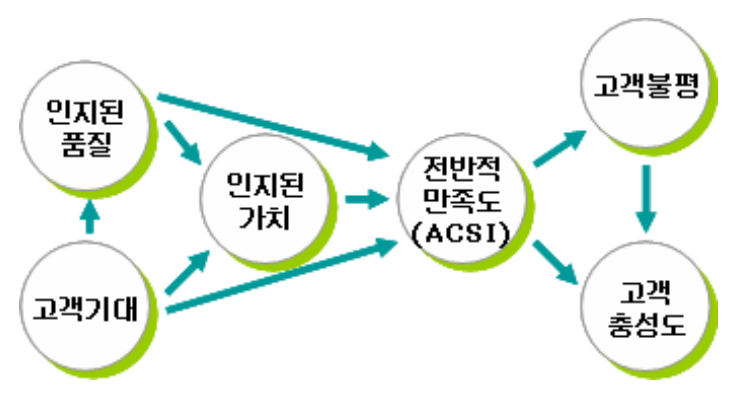

\section{III. 연구문제 및 연구방법}

\section{1 연구문제}

온라인 구전의 한 종류인 온라인 고객 리뷰에 는 다양한 내용을 포함하고 있는데, 주로 제품 및 서비스 사용의 만족 혹은 불만족, 구매동기, 재구매의향, 추천여부 등이다. 따라서 상이한 제품들의 리뷰들은 의미 및 구성면에서 다를 것으로 예상되며, 리뷰가 존재하는 채널에 따라 서도 리뷰들은 다른 구성을 보일 수 있다. 본 연구에서는 이와 같이 리뷰가 존재하는 채널,
제품의 속성, 제품의 가격에 따라 리뷰들이 어 떻게 다른 구성을 갖는지를 살펴볼 것이다. 이 를 위해서는 각각의 고객 리뷰가 어떻게 구성 되는가에 대한 기본적인 분류 체계가 필요하다. 박철과 정수연(2006)의 연구에서 리뷰길이, 평 가방향성 등에 대해 온라인 고객 리뷰의 내용 분석이 시행되었으나, 리뷰를 구성하는 구체적 인 분류 항목의 도출이 이루어진 연구는 없어, 본 연구에서 의미 중심의 내용 분석을 통해 온 라인 고객 리뷰의 분류 항목을 도출해보고자 한다. 고객 리뷰에는 해당 제품에 대한 만족도 과 관련하여 여러 가지 내용이 언급되기 때문 에 고객만족도를 기반으로 선행, 후행 변수를 가지고 있는 ACSI모델의 구성 개념에 해당하 는 내용들을 포함할 가능성이 많다. 따라서 본 연구에서는 ACSI모델에 기반하여 분류 항목을 도출할 것이다.

소비자들이 온라인 고객 리뷰를 접하는 채널 은 크게 두 가지로 나누어 볼 수 있다. 첫째는 기업에서 공식적으로 운영하는 기업 홈페이지 가 있는데, 이곳에는 자사의 상품 및 서비스 소 개와 상품을 사용한 홈페이지 회원들의 고객 리뷰가 있다. 다른 하나는 다양한 제품의 판매 가 이루어지는 쇼핑몰에서 주로 쇼핑몰의 구매 자들이 고객 리뷰를 작성하여 올리는 경우이다. 두 채널의 운영주체가 다르고 리뷰 작성자들의 특징도 다르기 때문에 리뷰의 구성이 다를 것 이라고 예상된다.

Nelson(1974)은 구매 전후에 소비자들이 품질 을 확인할 수 있는지를 기준으로 제품을 탐색 재(search goods)와 경험재(experience goods) 로 분류하였다. 탐색재는 구매하기 전에 관련된 모든 속성 정보를 얻을 수 있는 제품을 의미하 
며, 경험재는 구매하기 전에는 알기 힘든 속성 들을 가진 제품으로 정의된다. 온라인 고객 리 뷰는 고객들이 제품을 사용한 후, 사용경험과 관련된 이야기를 다른 소비자를 위해 글로 남 기는 것으로 특히 경험재에 더 의미가 있을 것 으로 예상되는데, 경험재를 구매하려는 소비자 는 탐색재를 구매할 때에 비해 다른 소비자들 의 의견과 같은 온라인 정보를 더욱 중요하게 여기기 때문이다(Bei et al. 2004). 한편 가격은 구매 결정시 가장 기본적인 속성 중 하나이며 (Zeithaml 1988), 제품의 가격에 따라 소비자들 의 제품에 대한 관여도가 달라지고 그에 따른 리뷰 구성의 차이가 예상되어 가격에 따라 제 품을 나누어 보았다.

이상의 이론적 배경 하에 다음과 같은 연구 문제를 설정하였고〈그림 2〉에서 연구의 개념 적 프레임워크를 나타내었다.

- 온라인 고객 리뷰는 어떠한 분류 항목들로 구성되어 있는가?

- 온라인 고객 리뷰가 존재하는 채널(자사홈 페이지/쇼핑몰)에 따라 분류항목과 만족도 에서 차이가 있는가?
- 제품의 속성(경험재/탐색재)에 따라 분류 항목과 만족도에서 차이가 있는가?

- 제품의 가격(고가/저가)에 따라 분류항목 과 만족도에서 차이가 있는가?

\section{2 내용분석법}

내용분석법(Content Analysis)은 기존 통계 자료 분석과 함께 간접적 조사방법의 하나이다. 간접적 조사방법은 조사자로 하여금 조사하고 자 하는 현상과 과정에 대해 영향을 미치지 않 으면서 연구할 수 있다는 장점이 있다. 내용 분 석은 특히 커뮤니케이션에 관한 연구에 매우 적합하다(소영일 1994). 즉, “누가, 무엇을, 누 구에게, 왜, 어떻게, 그리고 어떤 영향을 가지고 서 말하는가?”라는 커뮤니케이션 연구의 전통 적 질문에 대해 정확하고 풍부한 정보를 획득 하는데 적합한 조사방법이라 할 수 있다(e.g., 박찬욱과 김형수 2008). 내용분석법은 소비자조 사에 있어 몇 가지 장점을 지니고 있다. 첫째, 설문조사처럼 소비자들과 직접 커뮤니케이션하 지 않아 편향되지 않은 정보 획득이 가능하고,

〈그림 2〉 연구의 개념적 프레임워크

\section{〈분석기준〉}

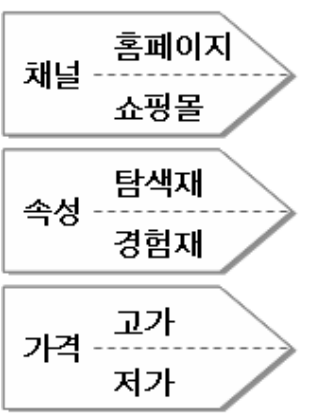

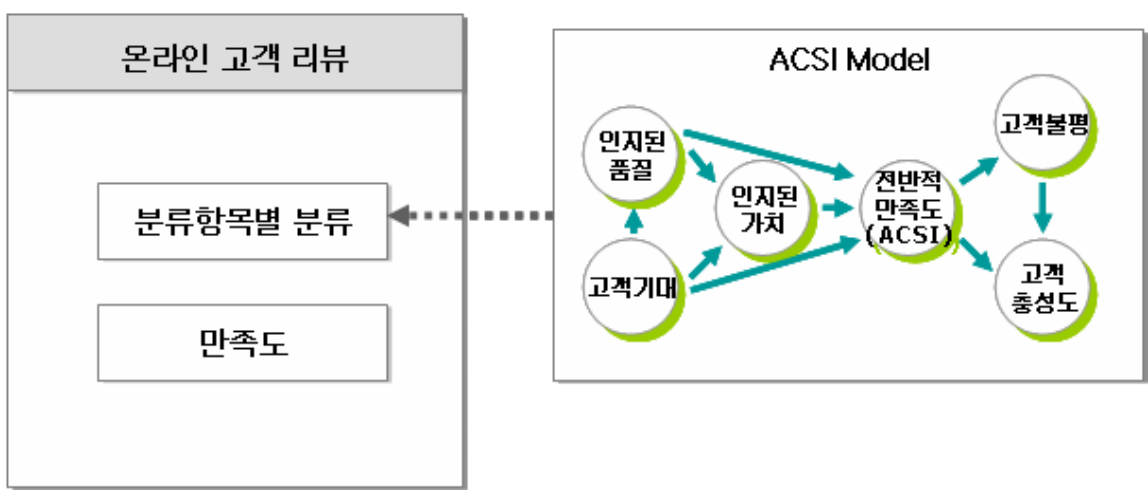

온라인 고객 리뷰의 분류 항목별 차이 분석: 채널, 제품속성, 가격을 중심으로 131 
둘째, 메시지내용과 관련된 다양한 변수들의 효 과를 알 수 있으며, 셋째, 새로운 연구의 시작 점을 제시해주며, 넷째, 다방법(multimethod) 연구에서 쓰일 수 있다. 반면 데이터획득, 분석, 해석에 있어 조사자의 주관이 들어가기 쉽다는 단점이 있다(Kolbe and Burnett 1991). 온라인 구전의 한 형태인 온라인 고객 리뷰는 인터넷 을 통해 이미 문서화 되어 있는 자료이기 때문 에 현상을 있는 그대로 분석할 수 있으며, 고객 리뷰에 대한 사전 연구가 많지 않기 때문에 내 용분석법을 통한 탐색적 연구가 적합하다고 판 단하여 본 연구에서 적용하였다.

\section{3 조사대상 및 분류방법}

온라인 구전의 한 종류인 고객리뷰의 구성을 살펴보기 위해 채널, 제품속성, 가격을 기준으 로 조사 대상을 선정하였다. 분석대상을 선정하 는데 있어 가장 크게 고려되었던 것이 분석을 위한 충분한 양의 고객 리뷰였다. 따라서 다양 한 제품들의 홈페이지에 있는 리뷰의 개수와 인터넷 쇼핑몰에 존재하는 리뷰의 개수를 고려 하여 분석에 충분한 리뷰의 개수를 보유한 제 품으로 탐색재로는 $\mathrm{mp} 3$, 경험재로는 마스카라 를 분석 대상으로 선택하였다. 인터넷 쇼핑몰은 시간당 방문자수로 카테고리별 웹사이트 순위 를 공개하는 랭키닷컴(http://www.rankey.com) 에서 종합쇼핑몰부문 1 위를 차지하는(해당분야 점유율 $23.05 \%$ ) 인터파크의 고객 리뷰를 이용 하였다. 구체적 분석대상은 〈표 4>에 정리되어 있다.

본 연구에서 사용한 내용분석 단위인 맥락단 위는 기록단위만으로 정확한 분석이 불가능할
때 전체적인 문맥을 고려하여 분석대상으로 하 는 것이다. 맥락 단위는 독립적일 필요도 없고 분리하여 기술되어 있는 것도 아니며, 한 문맥 단위가 한 행이 될 수도 있고, 또는 한 쪽이 될 수도 있다(Krippendorf 1980). 본 연구의 맥락단 위는 리뷰 작성자의 경험이나 의견, 지식을 담고 있는 최소 단위로 하였으며 따라서 하나의 리뷰 안에서 맥락단위의 수에 따라 서로 다른 몇 개 의 내용이 존재하는가를 파악할 수 있다. 물론 리뷰에 따라 맥락단위를 전혀 갖지 않은 경우도 발생할 수 있다. 고객 리뷰는 정해진 형식 없이 고객이 원하는 대로 작성하기 때문에 짧은 문장 에 여러 의미가 포함될 수도 있고, 긴 문장이지 만 단순한 감탄사나 의미없는 글자들로 채워지 기도 한다. 특히 고객 리뷰 작성을 유도하기 위 해 다양한 인센티브 제도를 도입하면서 의미없 는 리뷰들이 많이 생산되었다. 따라서 각각의 고 객 리뷰에서 의미있고 실질적인 내용을 파악하 기 위해서는 맥락단위의 수로 수치화시키는 것 이 바람직하다. 즉 하나의 리뷰에 맥락단위의 수 가 많을수록 그 리뷰는 의미있고 많은 내용을 담고 있는 자세한 리뷰라고 할 수 있다. 본 연구 에서는 전체 리뷰를 맥락단위로 분류한 후, 비슷 한 내용을 그룹화하여 분류항목을 도출하였다.

분류 항목을 도출하는 작업은 반복적인 작업 을 거쳐 완성되었다. 먼저 이 분석에 참가한 세 명의 분석자 가운데 첫번째 분석자가 전체 리 뷰를 맥락단위로 나누었다. 그리고 나누어진 맥 락단위들을 ACSI 모델을 이루고 있는 구성 개 념(construct)을 기본으로 하여 분류를 하고, 분류되지 않은 맥락단위를 의미에 맞게 그룹화 하는 작업을 반복하여 최종적으로 분류 항목을 완성하였다. 분류 항목은 크게 세 단계로 이루 
어져 있다. 먼저 1 단계 분류로 제품과 서비스를 분류하였다. 2단계로는 제품에서 기능, 디자인, 가격, 구매동기, 제안/사용팁, 추천/재구매 항목 으로 분류하였고, 서비스에서는 $\mathrm{AS} /$ 업그레이 드, 배송/기타 항목으로 분류하였다. 2단계에서 도출된 분류 항목이 $\mathrm{ACSI}$ 의 구성 개념과 가장 유사한데, 기능과 디자인은 ACSI의 인지된 품 질, 가격은 인지된 가치, 구매동기는 고객기대, 제안/사용팁과 추천/재구매는 고객충성도, AS/ 업그레이드와 배송/기타는 ACSI의 인지된 품 질을 나타내고 있다. ACSI의 전반적 만족도와 고객불평은 각 항목에서 함께 언급되고 있어 따로 분류 항목을 구성하지 않았다. 마지막 3 단 계 분류에서는 2 단계에서 도출된 분류 항목들 에 속하는 맥락단위들을 조사에 선정된 제품에 특화된 항목들로 그룹화하였다. 즉, 본 연구에
서 탐색재로 선택된 MP3의 3단계 분류 항목들 은 “음질, 용량, 메뉴편의성” 등을 포함하고 있 고, 경험재로 선택된 마스카라는 “발림성, 컬 링” 등의 분류 항목을 포함하고 있다. 3 단계 분 류 항목에서는 분석 대상으로 선택한 탐색재와 경험재의 제품 자체의 속성 차이가 있기 때문 에 기능, 디자인 항목에서 서로 다른 세부 항목 들이 나타남을 알 수 있다. 본 연구에서는 탐색 재와 경험재의 효과적인 비교를 위해 주로 2 단 계 분류 항목들의 차이 분석을 시행하였지만, 3 단계 분류 항목 도출을 통해 맥락단위들의 2 단 계 분류를 보다 명확히 할 수 있었다. 〈표 2〉 에서는 탐색재와 경험재의 3 단계의 분류 항목 들을 나타내고 있으며, 〈표 3〉은 분류의 예시 이다.

분류 항목의 도출과 더불어, 세 명의 분석자

〈표 2〉 탐색재와 경험재의 분류항목

\begin{tabular}{|c|c|c|c|}
\hline \multirow{2}{*}{ Level1 } & \multirow{2}{*}{ Level2 } & \multicolumn{2}{|c|}{ Level3 } \\
\hline & & 탐색재 & 경험재 \\
\hline \multirow{6}{*}{ 제품 } & 기능 & $\begin{array}{l}\text { 음질, 용량, 알람, 시계, 다양한기능, 재생시 } \\
\text { 간, 컴퓨터연결 및 프로그램, 조작 및 메뉴 } \\
\text { 편의성, 배터리/충전지, 이어폰, USB덮개문 } \\
\text { 제, 이동식디스크, 파일지원(OGG), 메뉴언 } \\
\text { 어, 녹음, 사용설명서, 다운로드속도, 작동 } \\
\text { 오류, 기능오류, 노이즈, 라디오, 재생속도 } \\
\text { 조절, USB내장, TTS, 기타 }\end{array}$ & $\begin{array}{l}\text { 길어보임, 굳기/마름, 너구리/번짐, 뭉 } \\
\text { 침, 볼륨/풍성함, 깔끔, 마스카라색상, } \\
\text { 컬링/잘올라감, 발림성, 클렌징, 눈자극, } \\
\text { 솔, 지속력, 양, 유화액, 기타 }\end{array}$ \\
\hline & 디자인 & 크기, 무게, 외관, 색상, 캐링케이스, 전체적 & 케이스, 전체적, 크기 \\
\hline & 가격 & 가격대비 만족, 비싸다/싸다 & 가격대비 만족, 비싸다/싸다 \\
\hline & 구매동기 & $\begin{array}{l}\text { 다른제품과 비교, 주위추천 및 후기, 브랜 } \\
\text { 드를 믿고, 기타 }\end{array}$ & $\begin{array}{l}\text { 다른제품과 비교, 주위추천 및 후기, 브 } \\
\text { 랜드를 믿고, 기타 }\end{array}$ \\
\hline & 제안/사용팁 & 제안, 사용팁 & 제안, 사용팁 \\
\hline & 추천/재구매 & 다른사람에게 추천, 자신의 재구매다짐 & 다른사람에게 추천, 자신의 재구매다짐 \\
\hline \multirow{2}{*}{ 서비스 } & $\mathrm{AS} /$ 업그레이드 & $\mathrm{A} / \mathrm{S}$, 펌웨어 업그레이드 & \\
\hline & 배송/기타 & 쇼핑몰, 배송 & 쇼핑몰, 배송 \\
\hline
\end{tabular}


〈표 3〉분류 예시

\begin{tabular}{|c|c|c|c|}
\hline Level1 & Level2 & Level3 & 고객 리뷰 (예시) \\
\hline \multirow{4}{*}{ 제품 } & 기능 & 조작 및 메뉴편의성 & 제가 기계치인데도 작동법이 간편해요 \\
\hline & 기능 & USB내장 & $\begin{array}{l}\text { 특히 usb 포트가 본체에 붙어있어서 따로 케이블 연결하고 } \\
\text { 그러는 불편함이 없어 usb 드라이브로 최적이네요 }\end{array}$ \\
\hline & 디자인 & 색상 & 골드색상 상당히 좋습니다. 나름대로 고급스럽습니다. \\
\hline & 추천/재구매 & 다른사람에게 추천 & 구매 망설이시는 분들이 계시면 권해드립니다. \\
\hline 서비스 & $\mathrm{AS} /$ 업그레이드 & $\mathrm{A} / \mathrm{S}$ & $\begin{array}{l}\mathrm{A} / \mathrm{S} \text { 도 대만족이고요 } 1 \text { 년동안 사용자 과실로 인한 파손도 } \\
\text { 보상. }\end{array}$ \\
\hline
\end{tabular}

들은 각 리뷰의 “전반적 만족도”를 “만족”, “중간”, “불만족”의 3 단계로 분류하였다. 이는 $\mathrm{ACSI}$ 의 구성 개념인 전반적 만족도와 고객불 평과 유사하며, 분류 항목 도출시 명확하게 맥 락 단위로 구별하기가 힘든 경우가 많아 리뷰 에서 도출되는 전반적 만족도로 분류하였다. 본 연구에서는 2 단계 분류 항목들의 차이 분석과 더불어 만족도의 차이 분석을 시행하였다.

\section{4 신뢰도}

내용분석법이라는 방법론이 가진 한계로 조사 자의 주관성 개입을 들 수 있다. 이를 보완하기 위해 세 명의 분석자가 코딩을 시행하였고, 코 딩자간의 신뢰도는 세 분석자간의 일치코딩수 를 총코딩수로 나눈 값으로 산출하였다(Miles and Huberman 1994). 그 결과 분류 항목에 따 른 리뷰의 분류에서는 3 단계 분류항목에서 0.72 , 2단계 분류항목에서 0.91 의 신뢰도를 보였다. 본 연구에서 주로 관심을 갖는 것이 2단계 분 류항목이고, 이 항목에서의 일치도가 권장 신뢰 도인 0.85(Kassarjian 1977)를 초과하고 있다. 또한 전반적인 만족도 분류에 따른 일치도는
0.96 을 보여 권장 신뢰도를 초과한다. 3 명의 분 석자들의 의견이 불일치하는 항목에 대해서는 본 연구의 저자들이 검토 및 토의하여 분류를 확정하였다.

\section{IV. 연구결과 및 분석}

이번 연구에서 분석된 리뷰의 개수는 총 542 개, 맥락단위의 개수는 1893 개이다. 즉, 본 연 구의 조사대상의 한 개의 리뷰당 평균적으로 $1893 / 542$ = 3.493개의 의미가 담겨있음을 알 수 있다. 〈표 4〉는 전체분석대상을 나타낸다.

\section{1 채널에 따른 분석}

리뷰를 남기는 채널에 따라 맥락단위의 수를 비교한 결과 모든 분류 항목에서 채널 간에 유 의한 차이점을 보였으며, 대부분의 분류 항목에 서 쇼핑몰보다 자사 홈페이지의 맥락단위 개수 가 더 많은 것으로 나타났다(〈표 5〉 참조). 즉, 자사 홈페이지에 있는 리뷰가 더 많은 의미를 
〈표 4〉전체분석대상

\begin{tabular}{|c|c|c|c|c|c|}
\hline 속성 & 가격 & 대상 & 채널 & 분석리뷰개수 & 맥락단위개수 \\
\hline \multirow{4}{*}{ 탐색재 } & \multirow{2}{*}{ 고가 } & \multirow{2}{*}{ MP3 아이리버 } & 자사 홈페이지 & 40 & 319 \\
\hline & & & 쇼핑몰 & 93 & 183 \\
\hline & \multirow{2}{*}{ 저가 } & \multirow{2}{*}{$\mathrm{MP3}$ 아이옵스 } & 자사 홈페이지 & 39 & 217 \\
\hline & & & 쇼핑몰 & 95 & 289 \\
\hline \multirow{4}{*}{ 경험재 } & \multirow{2}{*}{ 고가 } & \multirow{2}{*}{ 마스카라 캐시캣 } & 자사 홈페이지 & 40 & 158 \\
\hline & & & 쇼핑몰 & 95 & 285 \\
\hline & \multirow{2}{*}{ 저가 } & \multirow{2}{*}{ 마스카라 미샤 } & 자사 홈페이지 & 40 & 190 \\
\hline & & & 쇼핑몰 & 100 & 252 \\
\hline & & & 합계 & 542 & 1893 \\
\hline
\end{tabular}

〈표 5〉 채널, 제품속성, 가격에 따른 분류항목별 차이와 만족도별 차이 결과

\begin{tabular}{|c|c|c|c|c|c|c|c|c|c|c|c|}
\hline \multirow[b]{2}{*}{$\begin{array}{l}\text { 분석 } \\
\text { 유형 }\end{array}$} & \multirow{2}{*}{\multicolumn{2}{|c|}{ 분석기준 }} & \multicolumn{3}{|c|}{ 채널 } & \multicolumn{3}{|c|}{ 제품 속성 } & \multicolumn{3}{|c|}{ 가격 } \\
\hline & & & $\begin{array}{c}\text { 자사 } \\
\text { 홈페이지 }\end{array}$ & 쇼핑몰 & $\mathrm{t}$ 통계량 & 탐색재 & 경험재 & $\mathrm{t}$ 통계량 & 고가 & 저가 & $\mathrm{t}$ 통계량 \\
\hline \multirow{8}{*}{$\begin{array}{c}\text { 분류 } \\
\text { 항목 } \\
\text { 별 }\end{array}$} & \multirow{6}{*}{ 제품 } & 기능 & 3.472 & 1.436 & $13.106 * *$ & 1.910 & 2.153 & -1.497 & 2.142 & 1.927 & 1.325 \\
\hline & & 디자인 & 0.711 & 0.230 & $6.927^{* *}$ & 0.693 & 0.058 & $10.568^{* *}$ & 0.440 & 0.303 & $2.091 *$ \\
\hline & & 가격 & 0.264 & 0.394 & $-2.897^{* *}$ & 0.371 & 0.342 & 0.703 & 0.228 & 0.482 & $-6.396 * *$ \\
\hline & & 구매동기 & 0.409 & 0.162 & $6.260 * *$ & 0.184 & 0.284 & $-2.709 * *$ & 0.198 & 0.270 & -1.951 \\
\hline & & 제안/사용팁 & 0.164 & 0.013 & $5.673^{* *}$ & 0.067 & 0.047 & 0.811 & 0.049 & 0.066 & -0.692 \\
\hline & & 추천/재구매 & 0.340 & 0.149 & $5.122 * *$ & 0.120 & 0.287 & $-4.927^{* *}$ & 0.216 & 0.193 & 0.662 \\
\hline & \multirow{2}{*}{ 서비스 } & $\mathrm{AS} /$ 업그레이드 & 0.214 & 0.021 & $6.820^{* *}$ & 0.154 & 0.004 & $5.752^{* *}$ & 0.104 & 0.051 & $1.995^{*}$ \\
\hline & & 배송/기타 & 0.013 & 0.248 & $-6.428^{* *}$ & 0.281 & 0.080 & $5.994^{* *}$ & 0.164 & 0.193 & -0.846 \\
\hline \multicolumn{3}{|c|}{ 맥락단위(Context Unit) } & 5.585 & 2.653 & $12.903^{* *}$ & 3.779 & 3.255 & $2.226^{*}$ & 3.541 & 3.485 & 0.235 \\
\hline \multirow{3}{*}{$\begin{array}{l}\text { 만족 } \\
\text { 도별 }\end{array}$} & & 만족 & $91.80 \%$ & $69.40 \%$ & & $80.80 \%$ & $80.40 \%$ & & $78.70 \%$ & $82.40 \%$ & \\
\hline & & 중간 & $6.90 \%$ & $20.40 \%$ & & $14.20 \%$ & $13.10 \%$ & & $15.20 \%$ & $12.20 \%$ & \\
\hline & & 불만족 & $1.30 \%$ & $7.20 \%$ & & $2.90 \%$ & $5.50 \%$ & & $4.00 \%$ & $4.40 \%$ & \\
\hline
\end{tabular}

주) * $p<0.05$

** $p<0.01$

내포하고 있어 더 자세하다고 말할 수 있다. 또 한 만족도에서도 자사 홈페이지의 리뷰가 쇼핑 몰의 리뷰보다 더 만족감을 표현하고 있다는
것을 알 수 있다. 똑같은 제품임에도 불구하고 채널에 따라 서로 다른 리뷰의 패턴을 보이는 것은 리뷰를 쓰는 작성자에 차이가 있다는 결 
론을 내릴 수 있다. 자사 홈페이지의 방문은 사 용자가 특별히 의도했을 때 발생하는 것이며 리뷰 작성을 위해서는 회원가입 등의 절차를 밟아야 한다. 반면에 쇼핑몰은 일반적으로 구매 시 이미 회원 가입이 되어있기 때문에 비교적 쉽게 리뷰를 작성할 수 있다. 그렇기 때문에 실 제 리뷰가 올라오는 속도나 개수는 쇼핑몰이 더 많았으나 본 분석결과에 따르면 내용의 자 세함은 오히려 반대로 나타났다(〈표 5〉참조, 리 뷰 1 개당 평균맥락단위 개수: 홈페이지 5.585 , 쇼핑몰 2.653). 이로 인해 자사 홈페이지의 리 뷰 작성자들은 시간과 노력을 들여 자세하고 긍정적인 리뷰를 작성한다는 점에서 쇼핑몰의 리뷰 작성자들보다 충성도 있는 고객임을 유추 할 수 있다. 한편 대부분의 쇼핑몰에서는 고객 리뷰가 다른 소비자들의 구매의사결정에 영향 을 미친다는 점을 인지하여 구매자들의 리뷰 작성을 장려하는 인센티브 제도를 시행하고 있 다. 하지만 쇼핑몰의 리뷰 작성자들 중에는 단 지 이러한 인센티브를 얻기 위한 사람들도 있 기 때문에 자사 홈페이지에 비해 리뷰 내용의 자세함이 떨어질 수 있다. 이는 리뷰 건당 지급 하는 인센티브 제도가 오히려 리뷰의 질을 떨 어뜨리기 때문에, 우수 리뷰 선별 등 추가적인 제도가 뒷받침되어야 함을 의미한다.

각각의 항목별로 살펴보면 해당 리뷰의 핵심 내용인 기능, 디자인에 대한 맥락단위의 개수는 자사 홈페이지가 쇼핑몰보다 많은 것으로 나타 나 자사 홈페이지의 리뷰들이 더 자세함을 알 수 있다. 소비자들은 자사 홈페이지의 리뷰를 통해서 다른 소비자들의 경험과 판단에 근거한 제품 특징을 얻을 수 있음을 인지하게 되고 이 러한 특징은 소비자들을 자사 홈페이지로 유인
하는 효과를 일으킬 수 있다. 반면 가격 항목은 판매가 함께 이루어지는 쇼핑몰의 특성상 쇼핑 몰에서 자사 홈페이지보다 더 많이 언급됨을 알 수 있다.

구매동기나 제안/사용팁의 항목에 대한 내용 도 자사 홈페이지에서 더 많이 언급됨을 알 수 있는데, 이는 대체적으로 자사 홈페이지에서는 단순히 제품에 대한 만족도와 특징뿐만 아니라 제품 구매, 사용 경험에서부터 요청 및 제안에 이르기까지 구매와 사용에 관한 일련의 과정이 리뷰에 언급되기 때문이다. 소비자들은 이러한 이야기를 통해서 소비자들간의 동질감을 얻고 제품 구매시 고려사항에 대한 조언을 얻기도 한다. 또한 이미 제품을 구매하여 사용하고 있 는 소비자들도 공감대를 얻고, 다른 소비자가 리뷰에서 제시한 사용팁을 바탕으로 더욱 효과 적으로 사용할 수 있다. 추천/재구매는 고객이 제품 사용을 하고 만족을 했을 때 구전과 함께 보이는 소비후행동(postpurchase behavior)의 한 종류이기 때문에 리뷰를 읽는 다른 소비자들에 게 많은 영향을 끼칠 수 있는 항목이다. 실제로 자사 홈페이지에서 만족감을 나타내는 리뷰가 더 많고, 추천/재구매의 맥락단위 개수도 자사 홈페이지에서 더 많다.

$\mathrm{AS} /$ 업그레이드 서비스는 자사 홈페이지에 있 는 리뷰에서 언급이 더 많은데 리뷰를 작성하 는 위치가 제조사의 자사 홈페이지이므로 제조 사가 제공하는 서비스 관련된 이야기를 더 많 이 하기 때문이라고 해석할 수 있다. 또한 배송 /기타 서비스에 대한 언급이 현격히 차이남을 알 수 있는데 이는 자사 홈페이지에 들어와 리 뷰를 남기는 고객들은 대부분 홈페이지가 아닌 다른 인터넷 쇼핑몰이나 오프라인에서 물건을 
구매한 고객들이고, 쇼핑몰의 리뷰에서는 대부 분 해당 쇼핑몰을 이용한 고객들이기에 이들은 쇼핑몰을 이용하면서 받은 배송 서비스에 대한 언급을 많이 하는 편이다.

\section{2 제품 속성에 따른 분석}

분류 항목 중 유의미한 차이를 보이는 부분은 디자인 항목으로 경험재에 비해 탐색재에서 디 자인에 대한 언급이 더 많음을 알 수 있다. 탐 색재와 경험재의 주된 차이점은 구매전후에 제 품과 관련된 속성을 알 수 있고 판단할 수 있 는지의 여부에 따라 결정된다. 탐색재의 경우 이미 제공되는 속성 정보로 인해 기능에 대한 인지가 보다 쉽기 때문에 디자인에 더 관심을 갖는 경향이 있음으로 해석할 수 있다. 구매동 기는 탐색재에서보다 경험재에서 더 많이 언급 되는데 경험재의 경우 구매 전에 제품에 대해 서 판단을 하는 것이 힘들기에 소비자들은 제 품 구매시 이러한 위험을 줄이려고 노력할 것 이다. 따라서 경험재일수록 다른 사람들에게 자 신이 구매하게 된 동기를 공유하고자 하는 욕 구가 더 크다고 해석할 수 있다. 추천/재구매는 경험재에서 더 많이 언급되고 있다. 여기서 흥 미로운 것은 앞절에서 설명했던 채널별 차이와 는 달리 속성별 차이에서는 탐색재와 경험재의 만족도 차이가 거의 없다는 점이다. 따라서 추 천을 하거나 재구매 의사를 밝히는 것은 만족 도뿐만 아니라 제품 속성에서도 기인할 수 있 다는 결론을 내릴 수 있다. 경험재의 특성상 구 매하여야 그 특징을 알 수 있으므로 미리 경험 한 사람들이 다른 사람들을 위해 추천을 하거 나 자신이 재구매를 하고 싶다는 것으로 해석
할 수 있으며 이는 경험재에서 구매동기가 더 자세히 언급되는 것과 비슷한 이유라고 할 수 있다. Bei et al.(2004)의 연구에서도 알 수 있 듯이 경험재를 구매하려는 소비자는 탐색재를 구매할 때에 비해 다른 소비자들의 의견과 같 은 온라인 정보를 얻으려는 경향이 있다.

$\mathrm{AS} /$ 업그레이드 서비스는 탐색재에서 더 많이 언급되는데, 이는 탐색재와 경험재의 특성도 있 겠지만, 분석에 사용된 제품들이 각각 내구재와 비내구재의 특성을 가지고 있기 때문이라고 해 석할 수 있다. 내구재는 사용기간이 길고 가격 이 높은 제품들이고, 비내구재는 사용기간이 짧 고 가격이 비교적 낮으며 반복 구매되는 제품 들로 정의된다(Berkowitz 1992). 내구재는 비교 적 오래 사용하는 제품이기에 지속적으로 기업 으로부터 서비스를 제공받는 경우가 많다. 따라 서 서비스에 대한 니즈가 많고 실제로 그런 서 비스를 경험한 사람도 많기 때문에 리뷰에서도 많이 언급 되었다고 볼 수 있다. 배송/기타 서 비스 항목에 대한 차이도 분석에 사용된 제품 의 특징인 내구재/비내구재로 설명될 수 있다. $\mathrm{MP} 3$ 가 마스카라보다 일반적으로 가격이 비싸 고 자주 구매하는 제품이 아니기 때문에 소비 자들은 구매시 고관여(high-involvement)를 하 게 되고 배송에 민감하게 반응하게 된다. 실제 로 탐색재의 배송/기타 서비스 항목의 전체 맥 락단위 개수 중에 배송과 관련된 맥락단위의 개수가 차지하는 비율은 $87 \%$ 로, 경험재의 $68 \%$ 에 비해 높은 수치를 보임을 알 수 있다.

\section{3 가격에 따른 분석}

전반적인 맥락단위는 고가 제품이 저가 제품 
보다 높게 나타났지만 통계적으로 유의미한 차 이를 보이지는 않는다. 따라서 가격에 따라 리 뷰의 구체적인 정도는 차이가 나지 않음을 알 수 있다. 분류 항목중 가장 유의미한 차이를 보 이는 부분은 가격으로 저가 제품의 리뷰에서 가격에 대한 언급이 더 많음을 알 수 있다. 가 격 항목에 분류되는 맥락단위는 '가격이 저렴해 서 만족한다'등 가격 만족 언급뿐만 아니라 '가 격이 왜 이렇게 비싼지 모르겠다'등 가격에 대 한 불평도 함께 가격 항목으로 분류되었다. 따 라서 고가 제품에서는 가격에 대한 불만이, 저 가 제품에서는 가격에 대한 만족이 비슷하게 언급될 것으로 예상되었다. 하지만 고가, 저가 제품 모두 전반적인 만족도가 약 $80 \%$ 정도에 이르러 고가의 제품을 구매한 고객들에게도 가 격 요소가 불만사항으로 많이 언급되지 않았고, 상대적으로 저가 제품의 고객들은 저렴한 가격 요소까지 만족사항으로 언급하여 둘 사이의 차 이점을 가져오게 되었다.

\section{$\mathrm{V}$. 결 론}

\section{1 연구의 요약 및 의의}

본 연구에서는 온라인 커뮤니케이션의 활성화 로 인해 기업과 소비자 모두 관심을 기울이는 온라인 고객 리뷰를 내용분석법을 이용해 분류 항목을 도출하였다. 이를 기반으로 리뷰가 작성 되는 채널(홈페이지, 쇼핑몰), 제품의 속성(탐 색재, 경험재), 제품의 가격(고가, 저가)에 따라 분류 항목별 내용의 차이와 리뷰의 전반적인
만족도 차이를 살펴보고자 했다.

온라인 고객 리뷰의 분류를 위해서 내용분석 법을 이용하였고, 분류 항목을 설정하는데 있어 고객 만족도를 측정하는 $\mathrm{ACSI}$ 모델의 구성 항 목들을 근간으로 하였다. ACSI모델의 구성 항 목을 도입한 이유는 고객 리뷰가 해당 제품에 대한 고객의 만족도를 비롯하여 제품 특성, 구 매, 사용 경험 등을 일반적으로 포함하고 있기 때문이다. 분류 항목은 실제 리뷰의 반복적인 분류를 통해 확정 되었다. 분류 항목은 3 단계로 이루어져 있으며 1 단계는 제품과 서비스, 2 단계 는 제품에서 기능, 디자인, 가격, 구매동기, 제 안/사용팁, 추천/재구매, 서비스에서 $\mathrm{AS} /$ 업그 레이드와 배송/기타이며, 3단계는 실제 제품 리 뷰 내용을 바탕으로 2 단계 분류 항목의 세부항 목으로 작성되었다.

분석 결과로는 채널별 차이를 보기 위해 분석 한 홈페이지와 쇼핑몰에서의 리뷰 내용 차이가 가장 두드러지게 나타났다. 총 8 개의 분류 항목 에서 모두 유의한 차이점을 보였으며 쇼핑몰의 특성이 들어있는 가격과 배송/기타 서비스 항 목을 제외하고는 홈페이지에서의 맥락단위의 개수가 크게 나타남으로써 더 자세한 리뷰임을 알 수 있다. 또한 제품에 대한 만족도도 홈페이 지의 리뷰에서 더 큰 것으로 나타났다. 제품 속 성인 탐색재, 경험재로 분석해 보았을 때에는 디자인, 구매동기, 추천/재구매, $\mathrm{AS} /$ 업그레이드 서비스, 배송/기타 서비스 항목에서 서로간의 차이를 볼 수 있었으며 전반적인 만족도 차이 는 없었다. 가격별로 보았을 때에는 디자인, 가 격, $\mathrm{AS} /$ 업그레이드 서비스에서 고가와 저가의 차이를 볼 수 있었으며 전반적인 만족도 차이 는 없었다. 
본 연구는 다음과 같은 이론적 및 실무적 시 사점을 지니고 있다. 첫째, 내용 분석법을 통해 온라인 구전의 탐색적인 연구를 시도하였다. 본 연구에서는 기업들이 쉽게 획득할 수 있는 인 터넷에 존재하는 온라인 고객 리뷰의 내용 분 석을 바탕으로 분류 항목을 도출하고, 도출된 분류 항목을 기준으로 채널별, 제품 속성별, 가 격별로 고객 리뷰들이 어떠한 차이점을 보이는 지 밝혀내었다. 특히 온라인 고객 리뷰의 내용 자체를 분석한 연구가 드물고 이미 수행된 연 구도 의미 단위의 분석보다는 리뷰의 길이 등 을 통한 외적 형식의 분석에 치우쳐 있었으나, 본 연구에서는 맥락단위의 개념을 도입하여 리 뷰의 실질적인 내용을 분석했다는 점에서 기존 의 연구와 다른 점을 보이고 있다.

둘째, 온라인 고객 리뷰를 온라인 구전 뿐만 아니라 고객 지식의 관점에서도 고찰하였다. 지 식 경영에서는 조직 내에서 직원들 간의 지식 공유뿐만 아니라 조직의 범위를 벗어나 외부와 의 지식공유를 강조하고 있으며, 특히 고객 지 식의 획득 및 공유는 고객 지향적 기업이 되기 위한 가장 기본적인 요소이다(김형수 외 2008; Kim and Kim 2008). 온라인 고객 리뷰는 기업 에서 획득하기 쉬운 고객 지식의 한 종류이기 에 기업에서 꾸준히 관리하고 받아들일 필요가 있다. 본 연구에서는 온라인 고객 리뷰의 내용 분석을 통해 분류 항목을 도출함으로써 리뷰들 이 실질적인 고객 지식으로서 쓰일 수 있는 기 반을 제시하였다. 예를 들면, 기능, 디자인 측면 은 $\mathrm{R} \& \mathrm{D}$ 부서에서, 가격, 구매동기 등은 마케 팅 부서에서, $\mathrm{AS} /$ 업그레이드는 고객서비스 부 서에서 참고하고 받아들여야할 고객지식이 될 수 있다. 뿐만 아니라 대부분의 분류 항목에서
자사 홈페이지의 리뷰가 더 많은 내용을 담고 있지만, 가격 항목에서는 쇼핑몰에서 더 많은 내용을 담고 있기 때문에 가격에 대한 고객 반 응을 확인하기 위해 제품을 판매하는 쇼핑몰의 리뷰를 참조하는 등 목적에 따라 알맞은 채널 의 고객 리뷰 선택이 필요하다는 결론을 얻을 수 있다.

셋째, 실무적으로 기업들에게 자사 홈페이지 관리의 필요성에 대해 제안할 수 있다. 본 연구 결과를 통해 자사 홈페이지의 리뷰 특성이 쇼 핑몰의 리뷰 특성과는 다르다는 것을 보였다. 또한 같은 제품임에도 불구하고 만족하는 내용 의 리뷰가 홈페이지에 상대적으로 많으며 내용 면에 있어서도 많은 의미를 담고 있음을 알 수 있었다. 따라서 홈페이지에서 고객 리뷰의 운영 및 관리를 통해 충성도 있는 고객들을 파악하 고 관리할 수 있다. 또한 일반 소비자들은 회사 에서 제공하는 정보만이 아닌 다른 소비자들의 의견까지 원하기 때문에 보다 긍정적이고 풍부 한 리뷰를 홈페이지를 통해 제공하면서 이러한 소비자들의 홈페이지 방문을 유도할 수 있다.

넷째, 기업들에게 상품에 따른 온라인 고객 리뷰 관리에 대한 시사점을 제시한다. 먼저 제 품의 가격과 고객 리뷰의 자세함은 거의 관계 가 없는 것으로 나타났다. 일반적으로 저가의 제품에 대해서는 관여도가 낮아 고객 리뷰를 자세히 작성하지 않는다고 생각할 수 있지만 실제로는 고가의 제품과 비교했을 때 리뷰의 자세함에 있어서는 차이가 없기 때문에 저가 제품에 대한 고객 리뷰도 관리해야할 필요가 있다. 또한 제품 속성이 탐색재에 가까울 경우 경험재보다 고객 리뷰가 더욱 자세한 내용을 담고 있기 때문에 고객지식화하여 기업내에서 
활용될 여지가 많다. 이를 위해 각 분류항목별 로 채널별 특성을 비교하여 리뷰가 더 자세하 게 작성된 채널의 것을 취하는 것이 바람직할 것이다.

다섯째, 쇼핑몰의 인센티브 제도에 대한 시사 점을 제시한다. 대부분의 쇼핑몰에서는 고객 리 뷰 작성을 유도하기 위해 다양한 인센티브 제 도를 시행하고 있고, 이로 인하여 상당한 양의 고객 리뷰를 보유하고 있다. 하지만 본 연구결 과에서도 알 수 있듯이 자사 홈페이지보다 리 뷰의 자세함이 떨어지는 것으로 나타났다. 이는 단순히 리뷰 한 건의 작성에 대해 무조건적인 인센티브 제공의 효과성에 대해 의문을 갖게 한다. 고객 리뷰의 양적인 측면은 증대했지만 질적인 측면은 오히려 떨어지고 있기 때문이다. 이를 극복하기 위해 우수 리뷰를 선별해 더 많 은 인센티브를 주는 등의 추가적인 제도를 운 영할 필요가 있다.

\section{2 연구의 한계 및 향후 연구 방향}

위와 같은 연구의 의의에도 불구하고, 본 연 구는 몇 가지 명백한 연구를 한계를 가지고 있 다. 첫째, 리뷰 분석 대상의 선정에 있어서 제 품 가격대의 차이로 인해 체계적 오차의 가능 성을 배제할 수 없다는 점이다. 본 연구에서 다 루게 된 제품의 경우 연구의 취지상 탐색재와 경험재를 구분하고, 그 중에서도 소비자들의 리 뷰가 가장 많은 제품을 선정했다는 점에서 연 구의 내적 타당성을 확보할 수는 있겠지만, 일 반적으로 제품의 인지적 가치를 결정하는 주요 요인 중의 하나가 가격이고, 가격이 높고 낮음 에 따라 소비자의 내적 기대수준이 결정될 수
있으므로 결과적으로 리뷰의 내용이 체계적으 로 영향을 받을 가능성이 있다. 향후에는 탐색 재와 경험재의 구분과 더불어 고가와 저가의 구분을 추가하여 4 가지 분류에 속하는 제품들 에 대한 소비자 리뷰를 분석하면 더욱 정확하 고 의미 있는 연구가 될 것이다. 또한 가격과 더불어 탐색재와 경험재로 선정된 제품의 주 사용층의 고객특성 차이가 리뷰 작성에 차이점 을 가져올 가능성도 배제할 수 없다. 탐색재로 선정된 $\mathrm{mp} 3$ 는 남녀공용, 경험재로 선정된 마스 카라가 여성용임을 고려했을 때, 리뷰작성에 남 녀의 성향차이도 반영될 수 있기 때문이다. 향 후에는 이러한 고객특성 차이가 발생하지 않을 제품을 선정하여 보다 객관성 있는 분석을 할 수 있을 것이다.

둘째, 본 연구에서는 내용분석법이라는 연구 방법론을 사용하였는데, 내용분석법의 다양한 장점에도 불구하고 연구자의 주관성이 완전히 배제되지 못했을 수도 있다는 가능성이 존재한 다. 연구의 과정에서 3 명의 추가적인 연구자가 개별적인 분석을 시도하고, 저자들이 중재함으 로써 가급적 주관성을 배제하기 위해 노력하였 으나, 정성적 연구방법론들이 가지는 근본적인 한계로서 어느 정도 연구의 주관성이 존재할 수 있다. 향후 관련연구에는 리뷰의 내용을 바 탕으로 분석내용의 사전 항목화 및 정량적 코 드화를 수행하고, 텍스트 마이닝 (text mining) 과 같은 도구를 활용함으로써, 다양한 통계적 기법을 적용할 수 있을 것이다.

마지막으로, 본 연구에서 제기한 연구결과의 해석과 응용에 한계가 있다. 즉, 본 연구에서 온라인 리뷰의 분석을 통해 채널, 제품의 특성, 제품의 가격에 따른 리뷰 내용의 구성형태와 
전반적인 만족도를 파악해보는 것이었지만, 분 석 항목들간의 상관관계나 인과관계를 설명할 수 없고, 궁극적으로 소비자의 의사결정에 어떻 게 영향을 미치는 지에 대한 통찰력을 제공하 기 어렵다는 점이다. 현재의 연구는 기업의 핵 심적인 고객지식 확보를 위한 채널 관리라는 차원에서 의미를 가지고 있지만, 이것이 고객의 제품구매 의사결정을 유도할 수 있는 실질적인 마케팅전략으로 활용되기 위해서는 분석단위를 개념화하고, 실증연구를 통해 이들 간의 인과관 계를 검증해보는 것이 중요할 것이다.

〈논문 접수일: 2008. 01. 11〉

〈게재 확정일: 2008. 06. 23〉

\section{참고문헌}

강신형(2005), 신제품개발 과정에서의 온라인 브랜드 커뮤니티 활용에 대한 탐색적 연구, 한국과학기술원 석사학위논문.

김미주, 황의록(2004), "인터넷 쇼핑몰 이용자의 구전활동에 관한 연구," 한국유통학회, 3761.

김형수, 김승하, 김영걸(2008), “정보서비스 품 질이 고객로열티에 미치는 영향에 관한 연 구: 고객관계관리 관점," 경영정보학연구, 18(1), 1-23.

김형수, 박찬욱(2006), “AHP 기법을 활용한 CRM 평가요소의 상대적 중요도 분석," $\mathrm{CRM}$ 연 구, 1(1), 3-22.

박찬욱, 김형수(2008), "CRM 활동에 영향을 미 치는 요인들에 대한 탐색적 연구," 마케팅
관리연구, 13(1), 69-92.

박철, 정수연(2006), “온라인 소비자 구전에 대 한 내용분석: 사이트유형과 제품유형에 따 른 차이를 중심으로," 광고연구, 70, 91-118. 소영일(1994), 연구조사방법론, 박영사.

이유재, 이수진(2006), “고객 정보참여 행동의 결정요인과 관여의 조절역할: 구전과 협조 를 중심으로," 한국마케팅저널, 8(3), 13-40. 이은영(2004), 온라인 구전 수용과 확산 과정에 대한 이중경로 모형에 관한 연구: 구전 구 성요인과 커뮤니티 구성요인을 중심으로, 서울대학교 박사학위논문.

이태민, 박철(2006), “온라인 구전정보의 방향성 과 유형이 구매영향력에 미치는 효과: 한국 과 미국의 국제비교," 마케팅연구, 21(1), 29-56.

임종원, 이은영(2007), “온라인 구전효과의 영향 요인에 관한 연구," 한국마케팅저널, $8(4)$, 59-77.

정재학, 김영찬(2004), “구전 효과가 소비자 제 품 선택에 미치는 영향에 대한 연구," 마케 팅연구, 19(3), 1-20.

차태훈, 이경아(2006), “온라인 구전의 수용에 관한 연구 - 온라인 쇼핑몰의 사용후기를 중심으로," 광고연구, 72, 223-252.

Anderson, Eugene W. and Mary W. Sullivan (1993), "The Antecedents and Consequences of Customer Satisfaction for Firms," Marketing Science, 12(2), 125-143.

Arndt, Johan(1967), "Role of product-related conversations in the diffusion of a new product," Journal of Marketing Research, 4(3), 291. 
Bei, Lien-Ti, Etta Y.I Chen, and Richard Widdows(2004), "Consumers' Online Information Search Behavior and the Phenomenon of Search vs. Experience Products," Journal of Family and Economic Issues, 25(4), 449-467.

Berkowitz, Eric N., Roger A. Kerin, and William Rudelius(1992), Marketing, 3rd Ed., Irwin.

Bowman, Douglas and Das Narayandas(2001), "Managing Customer-Initiated Contacts with Manufacturers: The Impact on Share of Category Requirements and Word-ofMouth Behavior," Journal of Marketing Research, 38(3), 281-297.

Chatterjee, Patrali(2001), "Online Reviews Do Consumers Use Them?," Advances In Consumer Research, 28, 129-133.

Garcia-Murillo, M. and H. Annabi(2002), "Customer Knowledge Management," Journal of the Operational Research Society, 53, 875-884.

Herr, Paul M., Frank R. Kardes, and John Kim(1991), "Effects of Word-of-Mouth and Product-Attribute Information on Persuasion: An Accessibility-Diagnosticity Perspective," Journal of Consumer Research, 17(4), 454-462.

Hennig-Thurau, Thorsten and Gianfranco Walsh (2003), "Electronic Word-of-Mouth: Motives for and Consequences of Reading Customer Articulations on the Internet," International Journal of Electronic Com- merce, 8(2), 51-74.

Joshi, Ashwin W. and Sanjay Sharma(2004), "Customer Knowledge Development: Antecedents and Impact on New Product Performance," Journal of Marketing, 68, 4759.

Kassarjian, Harold H.(1977), "Content Analysis in Consumer Research," Journal of Consumer Research, 4(1), 8-18.

Kim, Hyung-Su and Young-Gul Kim(2008), "A CRM Performance measurement framework: Its development process and application," Industrial Marketing Management, (Forthcoming).

Kolbe, Richard H. and Melissa S. Burnett (1991), “Content-Analysis Research: An Examination of Applications with Directives for Improving Research Reliability and Objectivity," Journal of Consumer Research, 18(2), 243-250.

Krippendorff, Klaus(1980), Content Analysis: An Introduction to its Methodology, Sage, Beverly Hills, California.

Miles, Mattheu B. and A. Michael Huberman (1994), Qualitative Data Analysis: A Sourcebook of New Methods, Sage, Thousand Oaks.

Muniz Jr., Alert. M. and Thomas C. O’Guinn (2001), “Brand Community," Journal of Consumer Research, 27(4), 412-432.

Nelson, Phillip(1974), “Advertising as Information," Journal of Political Economy, 82 (4), 729-754. 
Nonaka, Ikujiro and Noboru Konno(1998), "The Concept of "Ba": Building a Foundation for Knowledge Creation," California Management Review, 40(3), 40-54.

Oliver, Richard. L. and Russell S. Winer(1987), "A Framework for the Formation and Structure of Consumer Expectations: Reviews and Propositions," Journal of Economic Psychology, 8, 469-499.

Park, Chung-Hoon and Young-Gul Kim(2003), "A Framework of Dynamic CRM: Linking Marketing with Information Strategy," Business Process Management Journal, 9 (5), 652-671.

Richins, Marsha L.(1983), "Negative Word-ofMouth by Dissatisfied Consumers: A Pilot Study," Journal of Marketing, 47(1), 68.

Rollins, Minna. and Aino Halinen(2005), "Customer Knowledge Management Competence: Towards a Theoretical Framework," Proceedings of the 38th Hawaii International Conference on System Sciences(HICSS).

Selnes, Fred(1993), "An Examination of the Effect of Product Performance on Brand Reputation, Satisfaction, and Loyalty," European Journal of Marketing, 27(9), 1935.

Sheth, Jagdish. N.(1971), "Word-of-Mouth in Low-Risk Innovations," Journal of Advertising Research, 11(3), 15-18.
Singh, Jagdip(1990), "Voice, Exit, and Negative Word-of-Mouth Behaviors: An Investigation across Three Service Categories," Journal of the Academy of Marketing Science, 18(1), 1-15.

Subramani, Mani R. and Balaji Rajagopanlan (2003), "Knowledge-Sharing and Influence in Online Social Networks via Viral Marketing," Communications of the ACM, 46(12), 300-307.

Sundaram, D. S., Kaushik Mitra, and Cynthia Webster(1998), "Word-of-Mouth Communications: A Motivational Analysis," $\mathrm{Ad}^{-}$ vances in Consumer Research, 25, 527-531.

Swan, John E. and Richard L. Oliver(1989), "Postpurchase communication by consumers," Journal of Retailing, 65(Winter), 516-533.

Tax, Stephen S., Stephen W. Brown, and Murali Chandrashekaran(1992), “Customer Evaluations of Service Complaint Experiences: Implications for Relationship Marketing," Journal of Marketing, 62, 6076.

Whyte, Jr., William H.(1954), "The web of word of mouth," Fortune, 50(5), 140-143.

Zeithaml, Valarie A.(1988), "Consumer Perceptions of Price, Quality, and Value: A Means-End Model and Synthesis of Evidence," Journal of Marketing, 52(3), 2-22. 


\title{
Analysis of Differences between On-line Customer Review Categories: Channel, Product Attributes, and Price Dimensions
}

\author{
Yang, So-Young* \\ Kim, Hyung-Su** \\ Kim, Young-Gul ${ }^{* * *}$
}

\begin{abstract}
Both companies and consumers are highly interested in on-line customer reviews which enable consumers to share their experience and knowledge about products. In this study, after classifying real reviews into context units and deriving categories, we analyzed differences between categories based on channel(manufacturers' homepage/ shopping mall), product attribute(search/experience) and price(high/low). The method to derive categories is based on roughly adopting constructs of ACSI model and elaborate and repetitive classification of real reviews. We set up the classification category with 3 levels. Level 1 consists of product and service, level 2 consists of function, design, price, purchase motive, suggestion/user-tip and recommendation/repurchase in product and AS/upgrade and delivery/others in service and level 3 is composed of details of level 2 of category. We could find remarkable differences between channels in all 8 items of level 2 of category. As the number of context units in homepage is more than in shopping mall, we found reviews in homepage is more concrete. Moreover, overall satisfaction in review was higher at homepage's. Also, in product attribute dimension, we found different patterns of reviews in design, purchase motive, suggestion/ user-tip, recommendation/repurchase, AS/up-grade and delivery/others and no difference in overall customer's satisfaction. In price dimension, we found differences between high and low price in design, price and AS/up-grade and no difference in overall customer's satisfaction.
\end{abstract}

Key words: Customer Review, Word of Mouth(WOM), Customer Knowledge, Content Analysis

\footnotetext{
* KT Marketing Laboratory

** Ph.D., Business Research Institute, Korea Advanced Institute of Science and Technology

*** Professor, Business School, Korea Advanced Institute of Science and Technology
} 


\section{Introduction}

In the contemporaries, product's experience and knowledge sharing via internet have become active according to the increase in usage of internet and in the number of consumers of e-commerce. 'Online customer review' is a written form of such usage experience and satisfaction in web pages, and it is a kind of word-of-mouth which has been researched in the field of marketing. In the perspective of research method, online customer review has a merit to observe and research without intervening in them. Moreover, Online customer review is important to business perspective as well as consumer perspective. It helps companies to get customer information and knowledge with comparatively low costs. However, since there aren't definite analysis criteria, converting online customer review into customer knowledge for companies has some limitations.

\section{Research Questions and Method}

Online customer reviews mainly include satisfaction or dissatisfaction of usage of product or service, purchase motive, intention to repurchase and recommendation. Hence, it is highly possible that they include the constructs of ACSI model, having antecedents and consequences based on customer satisfaction and we derived classification categories based on ACSI model. These are the research questions and $\langle$ Figure 1〉 shows the conceptual framework of this research.

- What are classification categories composing online customer review?

- Is there any differences between categories and satisfactions based on channels (manufacturers' homepage/ shopping mall) which online customer reviews are present?

- Is there any differences between categories

$\langle$ Figure 1〉 Conceptual framework of this research
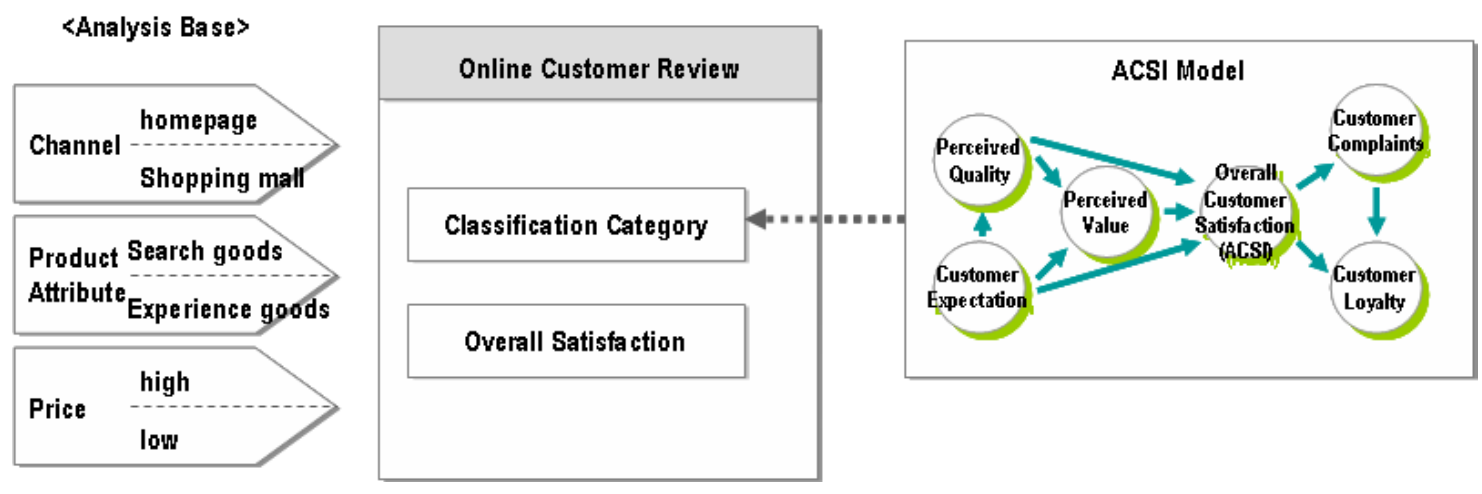

온라인 고객 리뷰의 분류 항목별 차이 분석: 채널, 제품속성, 가격을 중심으로 145 
and satisfactions based on product attributes(search/ experience goods)?

- Is there any differences between categories and satisfactions based on price (high/ low)?

In this paper, we derived classification categories by using content analysis based on context unit. They are composed of three levels. Level 1 consists of product and service, level 2 consists of function, design, price, purchase motive, suggestion/user-tip and recommendation/repurchase in product and AS/upgrade and delivery/others in service and level 3 is composed of details of level 2 of category. In this research, difference analysis in level 2 was conducted to compare effectively between search goods and experience goods. Also, we classified 'overall satisfaction' into satisfaction, middle and dissatisfaction. The reliability of level 2 classification was 0.91, and that of overall satisfaction classification was 0.96 , and both exceed recommended reliability 0.85 . The number of reviews analyzed in this research was 542, and the number of context units was 1893. That is, there were $1893 / 542=3.493$ context units in a review used in this paper on average.

\section{Results}

We could find remarkable differences between channels in all 8 categories in level 2 as referred to $\langle$ Table 1$\rangle$. As the number of context units in homepage was more than in shopping mall, we found reviews in homepage was more concrete. Moreover, overall satisfaction in review was higher at homepage's. Reviewers (consumers who write reviews after product consumption) in homepages are more loyal than that in shopping malls since they are usually willing to consume their efforts and time to write reviews in detail. Most shopping malls have recognized that customer reviews affect the other consumer's purchase decision and operate incentive systems which encourage consumers to write reviews. However, it may cause to deteriorate the quality of reviews in shopping mall due to some reviewers who only to write reviews to get incentives. It means additional systems need to be supported such as incentives only to reviewers who wrote superior quality of reviews. Purchase intention and suggestion/user-tip were mentioned more in homepage since not only simple satisfaction and characteristics of products but also whole processes from product purchase and usage experience to requests and suggestion were mentioned in reviews in homepage. Recommendation/ repurchase is one of postpurchase behaviors like word-of-mouth, and it can affect other consumers reading these reviews. In fact, the number of context units in recommendation/repurchase in homepage was more and overall satisfaction in review is higher. 
〈Table 1〉 Results of differences between categories and overall satisfaction based on channel, product attributes, and price dimensions

\begin{tabular}{|c|c|c|c|c|c|c|c|c|c|c|c|}
\hline & \multirow{2}{*}{\multicolumn{2}{|c|}{ Analysis Base }} & \multicolumn{3}{|c|}{ Channel } & \multicolumn{3}{|c|}{ Produc Attribute } & \multicolumn{3}{|c|}{ Price } \\
\hline & & & homepage & $\begin{array}{c}\text { shopping } \\
\text { mall }\end{array}$ & t-stat & $\begin{array}{l}\text { search } \\
\text { goods }\end{array}$ & $\begin{array}{l}\text { experience } \\
\text { goods }\end{array}$ & t-stat & high & low & t-stat \\
\hline \multirow{8}{*}{ 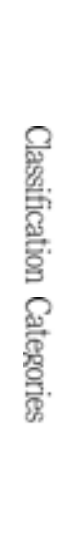 } & \multirow{6}{*}{ 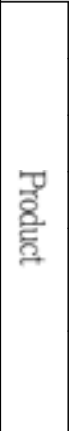 } & function & 3.472 & 1.436 & $13.106^{* *}$ & 1.910 & 2.153 & -1.497 & 2.142 & 1.927 & 1.325 \\
\hline & & design & 0.711 & 0.230 & $6.927^{* *}$ & 0.693 & 0.058 & $10.568^{* *}$ & 0.440 & 0.303 & $2.091^{*}$ \\
\hline & & price & 0.264 & 0.394 & $-2.897^{* *}$ & 0.371 & 0.342 & 0.703 & 0.228 & 0.482 & $-6.396 * *$ \\
\hline & & purchase motive & 0.409 & 0.162 & $6.260^{* *}$ & 0.184 & 0.284 & $-2.709^{* *}$ & 0.198 & 0.270 & -1.951 \\
\hline & & $\begin{array}{l}\text { suggestion/ } \\
\text { user-tip }\end{array}$ & 0.164 & 0.013 & $5.673^{* *}$ & 0.067 & 0.047 & 0.811 & 0.049 & 0.066 & -0.692 \\
\hline & & $\begin{array}{c}\text { recommendation/ } \\
\text { repurchase }\end{array}$ & 0.340 & 0.149 & $5.122 * *$ & 0.120 & 0.287 & $-4.927^{* *}$ & 0.216 & 0.193 & 0.662 \\
\hline & \multirow{2}{*}{ 萬 } & AS/up-grade & 0.214 & 0.021 & $6.820^{* *}$ & 0.154 & 0.004 & $5.752^{* *}$ & 0.104 & 0.051 & $1.995^{*}$ \\
\hline & & delivery/others & 0.013 & 0.248 & $-6.428^{* *}$ & 0.281 & 0.080 & $5.994^{* * *}$ & 0.164 & 0.193 & -0.846 \\
\hline \multicolumn{3}{|c|}{ Context Unit } & 5.585 & 2.653 & $12.903^{* *}$ & 3.779 & 3.255 & $2.226^{*}$ & 3.541 & 3.485 & 0.235 \\
\hline \multirow{3}{*}{ 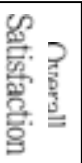 } & & Satisfaction & $91.80 \%$ & $69.40 \%$ & & $80.80 \%$ & $80.40 \%$ & & $78.70 \%$ & $82.40 \%$ & \\
\hline & & middle & $6.90 \%$ & $20.40 \%$ & & $14.20 \%$ & $13.10 \%$ & & $15.20 \%$ & $12.20 \%$ & \\
\hline & & Dissatisfaction & $1.30 \%$ & $7.20 \%$ & & $2.90 \%$ & $5.50 \%$ & & $4.00 \%$ & $4.40 \%$ & \\
\hline
\end{tabular}

$* p<0.05$

$* * \mathrm{p}<0.01$

In the results of analysis based on product attributes of search and experience goods, we found different patterns of reviews in design, purchase motive, suggestion/user-tip, recommendation/repurchase, AS/up-grade and delivery/ others and no difference in overall customer's satisfaction. Purchase intention was more mentioned in experience goods than search goods since experience goods are hard to evaluate before purchase and consumers try to reduce risks. Thus, It can be interpreted that consumers who bought experience goods have more desires to share the motives when they buy them. Recommendation/repurchase was mentioned more in search goods. The interesting thing here is that there are hardly differences in overall satisfaction between search goods and experience goods which is different from between categories based on channels. Therefore, recommendation or repurchase intention can be resulted from product attributes as well as satisfaction.

In price dimension, we found differences between high and low price in design, price 
and AS/up-grade and no difference in overall customer's satisfaction. Although the number of context units in high price was more than low price, it was not statistically different. The most remarkable difference between categories was price, and mentions related price were more in low price. The context units which were classified in price category were not only price satisfactory comments such as 'I satisfy low price' but also complaints such as 'I don't know why it's so expensive'. Thus, we had expected similar number of context units of both high and low price, for instance, complaints in high price and satisfaction in low price. However, overall satisfaction was about $80 \%$ of both high and low price products, and consumers who bought high price products didn't mention many complaints. As a result, as consumers who bought low price products mentioned low price as a factor of satisfaction, these caused the differences.

\section{Conclusions}

This paper has some theoretical and practical implications. First, as adopting the concept of context unit we tried to an exploratory research of online word-of-mouth analyzing substantial contents of online customer reviews. Second, as deriving classification categories through content analysis of online customer review we provided a foundation that reviews can be used to substantial customer knowledge. Third, the necessity of managing manufacturer's homepage is proposed since it can hoard loyal customer's reviews of great depth. Fourth, implications for managing online customer reviews based on product attributes and incentive system in shopping malls such as incentives for superior reviews are provided.

\section{Reference}

Anderson, Eugene W. and Mary W. Sullivan (1993), "The Antecedents and Consequences of Customer Satisfaction for Firms," Marketing Science, 12(2), 125-143.

Arndt, Johan(1967), "Role of product-related conversations in the diffusion of a new product," Journal of Marketing Research, 4(3), 291.

Bei, Lien-Ti, Etta Y.I Chen, and Richard Widdows(2004), "Consumers' Online Information Search Behavior and the Phenomenon of Search vs. Experience Products," Journal of Family and Economic Issues, 25(4), 449-467.

Berkowitz, Eric N., Roger A. Kerin, and William Rudelius(1992), Marketing, 3rd Ed., Irwin.

Bowman, Douglas and Das Narayandas(2001), "Managing Customer-Initiated Contacts with Manufacturers: The Impact on Share 
of Category Requirements and Word-ofMouth Behavior," Journal of Marketing Research, 38(3), 281-297.

Cha, Tai-hoon and Lee, Kyoung-a(2006), "Acceptance of Online Word-of-Mouth on Internet," Advertising Research, 72, 223-252.

Chatterjee, Patrali(2001), "Online Reviews Do Consumers Use Them?," Advances In Consumer Research, 28, 129-133.

Chung, Jai Hak and Young Chan Kim(2004), "An Analysis of WOM Effects on the Consumer Product Choice by Using a Hierarchical Bayesian Probit Model," Korean Marketing Review, 19(3), 1-20.

Garcia-Murillo, M. and H. Annabi(2002), "Customer Knowledge Management," Journal of the Operational Research Society, 53, 875-884.

Herr, Paul M., Frank R. Kardes, and John Kim(1991), "Effects of Word-of-Mouth and Product-Attribute Information on Persuasion: An Accessibility-Diagnosticity Perspective," Journal of Consumer Research, 17(4), 454-462.

Hennig-Thurau, Thorsten and Gianfranco Walsh (2003), "Electronic Word-of-Mouth: Motives for and Consequences of Reading Customer Articulations on the Internet," International Journal of Electronic Commerce, $8(2), 51-74$.

Joshi, Ashwin W. and Sanjay Sharma(2004), "Customer Knowledge Development: Antecedents and Impact on New Product
Performance," Journal of Marketing, 68, 47-59.

Kassarjian, Harold H.(1977), "Content Analysis in Consumer Research," Journal of Consumer Research, 4(1), 8-18.

Kim, Hyung Su and Chan-Wook Park(2006), "Establishing the Importance Weights of CRM Evaluation Factors through AHP Analysis," Journal of CRM Research, 1(1), 3-22.

Kim, Hyung Su, Seung Ha Gim and Young Gul Kim(2008), “The Effect of Information Service Quality on Customer Loyalty: A Customer Relationship Management Perspective," Journal of MIS Research, 18(1), $1-23$.

Kim, Hyung-Su and Young-Gul Kim(2008), “A CRM Performance measurement framework: Its development process and application," Industrial Marketing Management, (Forthcoming).

Kolbe, Richard H. and Melissa S. Burnett (1991), "Content-Analysis Research: An Examination of Applications with Directives for Improving Research Reliability and Objectivity," Journal of Consumer Research, 18(2), 243-250.

Krippendorff, Klaus(1980), Content Analysis: An Introduction to its Methodology, Sage, Beverly Hills, California.

Lee, Eun Young(2004), Two factor model of online word of mouth adoption and diffusion: the effects of information charac- 
teristics and community factors, Doctoral Dissertation, Seoul National University.

Lee, Thae Min and Cheol Park(2006), "Effects of Direction and Type of Electronic Word of Mouth Information on Purchase Decision: Cross-Cultural Comparison between Korea and U. S.," Korean Marketing Review, 21(1), 29-56.

Lim, Jong Won and Eun Young Lee(2007), "A Study of the Factors Influencing WOM Effects in Online Environments," Korean Journal of Marketing, 8(4), 59-77.

Miles, Mattheu B. and A. Michael Huberman (1994), Qualitative Data Analysis: A Sourcebook of New Methods, Sage, Thousand Oaks.

Muniz Jr., Alert. M. and Thomas C. O’Guinn (2001), "Brand Community," Journal of Consumer Research, 27(4), 412-432.

Nelson, Phillip(1974), “Advertising as Information," Journal of Political Economy, 82 (4), 729-754.

Nonaka, Ikujiro and Noboru Konno(1998), "The Concept of "Ba": Building a Foundation for Knowledge Creation," California Management Review, 40(3), 40-54.

Oliver, Richard. L. and Russell S. Winer(1987), "A Framework for the Formation and Structure of Consumer Expectations: Reviews and Propositions," Journal of Economic Psychology, 8, 469-499.

Park, Choel and Chung, Soo-yeon(2006), “A Content Analysis of Online Consumer
Reviews in Korea," Advertising Research, 70, 91-118.

Park, Chan Wook and Hyung Su Kim(2008), "An Explorative Study on the Factors Influencing Corporate CRM Activities," Journal of Marketing Management, 13(1), 69-92.

Park, Chung-Hoon and Young-Gul Kim(2003), "A Framework of Dynamic CRM: Linking Marketing with Information Strategy," Business Process Management Journal, 9(5), 652-671.

Richins, Marsha L.(1983), "Negative Word-ofMouth by Dissatisfied Consumers: A Pilot Study," Journal of Marketing, 47(1), 68. Rollins, Minna. and Aino Halinen(2005), "Customer Knowledge Management Competence: Towards a Theoretical Framework," Proceedings of the 38th Hawail International Conference on System Sciences (HICSS).

Selnes, Fred(1993), "An Examination of the Effect of Product Performance on Brand Reputation, Satisfaction, and Loyalty," European Journal of Marketing, 27(9), 19-35.

Sheth, Jagdish. N.(1971), "Word-of-Mouth in Low-Risk Innovations," Journal of Advertising Research, 11(3), 15-18.

Singh, Jagdip(1990), “Voice, Exit, and Negative Word-of-Mouth Behaviors: An Investigation across Three Service Categories," Journal of the Academy of Marketing Science, 18(1), 1-15. 
Subramani, Mani R. and Balaji Rajagopanlan (2003), "Knowledge-Sharing and Influence in Online Social Networks via Viral Marketing," Communications of the ACM, 46 (12), 300-307.

Sundaram, D. S., Kaushik Mitra, and Cynthia Webster(1998), "Word-of-Mouth Communications: A Motivational Analysis," $\mathrm{Ad}^{-}$ vances in Consumer Research, 25, 527531.

Swan, John E. and Richard L. Oliver(1989), "Postpurchase communication by consumers," Journal of Retailing, 65(Winter), 516-533.

Tax, Stephen S., Stephen W. Brown, and Murali Chandrashekaran(1992), "Customer
Evaluations of Service Complaint Experiences: Implications for Relationship Marketing," Journal of Marketing, 62, 60-76.

Whyte, Jr., William H.(1954), "The web of word of mouth," Fortune, 50(5), 140-143.

Yi, You Jae and Soo Jin Lee(2006), "Determinants of Customers' Information Engagement and the Moderating Effect of Involvement: Focused on WOM and cooperation," Korean Journal of Marketing, 8(3), 13-40.

Zeithaml, Valarie A.(1988), "Consumer Perceptions of Price, Quality, and Value: A Means-End Model and Synthesis of Evidence," Journal of Marketing, 52(3), 2-22. 